\title{
AMERICAN PHILANTHROPY IN REPUBLICAN TURKEY: THE ROCKEFELLER AND FORD FOUNDATIONS
}

\author{
MURAT ERDEM - KENNETH W. ROSE
}

\begin{abstract}
Through the work of missionary organizaions, American charity and philanthropy have had a long history in Turkey. Early in the twentieth century, however, charity and philanthropy within the United States underwent a dramatic change with the development of scientific philanthropy. Such efforts aimed, through investigation and careful use of financial contributions, to attack the heart of social ills rather than to relieve suffering or provide religious instruction. A host of Rockefeller philanthropies, the largest of which was the Rockefeller Foundation (RF-established in 1913), were in the forefront of scientific philanthropy in education, public health nursing and medical education, and support for scientific research. During the 1950s the Ford Foundation surpassed the RF in the size of its assets and soon rivaled the scope of its work internationally. This essay will examine the work of these two American philanthropies in Turkey since the declaration of the republic. Among the questions to be addressed are the relationship between private American foundations and the US and Turkish governments, the nature of philanthropic programs in Turkey and whether these changed over time, the cultural and political contexts to these philanthropic programs. Finally, the essay will assess what impact the work of these foundations has had in Turkey.
\end{abstract}

\section{KEYWORDS}

Turkey and the United States; Philanthropy; Ford Foundation; Rockefeller Foundation. 


\section{Introduction}

In 1957, a 31-year-old journalist from Turkey, Bülent Ecevit, received a fellowship from a foundation in the United States to spend a year at Harvard University. There he would study journalism and intercultural understanding, "with a particular emphasis on social psychology as related to underdeveloped areas." Ecevit and his wife arrived in the US on January 13, and he soon reported to his sponsors that he was spending most of his time reading and wanted to try to write a book during his time at Harvard. A few months later he reported that most of his reading was in Ottoman history, and that he found "great advantage in reading in a library where there is little or no difficulty in following up leads." Despite the leisure and the advantages that he enjoyed at Harvard, Ecevit soon felt compelled to return to Turkey ahead of schedule. In early September he announced to his hosts that elections in Turkey had been called for October 27, and he thought he should return to his newspaper as soon as possible. On September 16, the Ecevits left the U.S. to return to Turkey, where he was elected to Parliament. In December, Ecevit wrote to his American hosts that he was "doubly grateful" for the opportunity to study at Harvard. ${ }^{1}$

Bülent Ecevit's nine-month visit to the US was funded by the R.ockefeller Foundation (RF), one of the handful of a new kind of institution that had emerged during the Progressive era: the privately endowed, general purpose, grant-making foundation. As one of the largest of these new institutions, the RF arguably was the most important American foundation during the first half of the twenticth century. Among its distinguishing features has been its work outside of the US. Between 1925 and 1983, for example, the F.F provided fellowships that allowed 162 Turks to undertake a period of study outside of their own country. In a slightly shorter period, between 1929 and 1967, the RF granted financial support to 119 institutions in Turkey for various purposes. The Ford Foundation (FF), which grew to rival the RF's international influence in the second half of the century, made grants totaling more than $\$ 16$ million in Turkey between 1952 and the end of

${ }^{1}$ Fellowship Recorder Card for Bülent Ecevit, Rockefeller Foundation Archives, at the Rockefeller Archive Center, Sleepy Hollow, New York, hereafter designated as the RFA. 
1971. Together, the Rockefeller and Ford foundations invested substantial money and time toward the modernization of Turkish society in the twentieth century, working quietly behind the scenes, for the most part, to develop and support institutions in key segments of Turkish society: public health and medical care, agriculture, education, science, the social sciences, and business and industrial development.

American charitable and philanthropic work in Turkey dates to early 1820 , when the first missionaries from the US arrived in present-day İzmir. The work begun on behalf of the American Board of Commissioners for Foreign Missions by the Rev. Pliny Fisk and Levi Parsons by 1914 had grown to include 17 major mission stations, nine hospitals, and 426 schools serving 25,000 students. Religious work among the Christian minorities, education, and general relief of distress and sickness occupied much of the missionaries' efforts in Turkey during this time. ${ }^{2}$ But intellectual and organizational changes within the US in the period between 1880 and 1920 brought about a new kind of philanthropy in the first decades of the $20^{\text {th }}$ century. A more scientific approach to charity and philanthropy emerged within the US during this period. A combination of factors; the idea that the scientific method of observation and investigation could be applied to problems among and between human beings as well as to problems in the physical world; the rapidly accumulating fortunes of the new industrialists and financiers like Andrew Carnegie, John D. Rockefeller, and Russell Sage; and their experience with the new forms of business organization, the corporation and the trust contributed to the development of the privately endowed grantmaking foundation in the early years of the twentieth century. These new institutions did not replace the older religious-based charities, which continued their work; but the new foundations such as the General Education Board (1903), the Russell Sage Foundation (1906), the Rockefeller Sanitary Commission for the Eradication of Hookworm (1909), the Carnegie Corporation (1911), the RF (1913), the Julius Rosenwald Fund (1917) and the Commonwealth Fund (1918) soon became powerful and

${ }^{2}$ Roger R. Trask, The United States Response to Turkish Nationalism and Reform, 1914-1939, Minneapolis, The University of Minnesota Press, 1971, pp. 4, 9-10. 
influential voices in matters of education, health care, and public policy. ${ }^{3}$

More than 47,000 philanthropic foundations were established in the US during the $20^{\text {th }}$ century. Even though such foundations use private money for matters of public welfare, they are generally free from government control: As long as they meet certain guidelines regarding their grants, they are exempt from paying taxes, for example. As such, they are often characterized as constituting an "independent" or "third" sector of American society, distinct from the profit-driven world of business and the taxsupported world of government. While not unique to the US, such philanthropic foundations and the many more not-for-profit organizations that have arisen in ficlds of education, public policy development, medical research, and the provision of health care and social services help give the political economy of the US a distinct character. ${ }^{4}$

Historian David Hammack has described six distinct approaches that philanthropic foundations use to achieve their stated goals of improving the welfare of people. Although Hammack's discussion relates specifically to how American foundations have behaved within the confines of the American political and cultural context, his framework provides a guide to the behavior abroad of American foundations that have historically worked in other nations. Hammack notes that foundations have "provided direct support for scientific and scholarly research." They also have "sought to shape public opinion by supporting studies that highlight particular problems and devise and advance particular policies." Third, foundations have "supported and honored those whose actions they consider exemplary." Fourth, they have "helped devise and promote specific government

\footnotetext{
${ }^{3}$ For a general overview of the history of philanthropy in the United States, see Robert H. Bremner, American Philanthropy, 2nd ed., Chicago, University of Chicago Press, 1988.

${ }^{4} \mathrm{~A}$ substantial literature on foundations and the non-profit sector has developed within the past quarter-century. See the bibliographic essay in Bremner's American Philanthropy and the annotated bibliography prepared by Susan Kastan, "Recent Writings about Foundations in History", in Ellen Condliffe Lagemann (ed.), Philanthropic Foundations: New Scholarship, New Possibilities, Bloomington and Indianapolis, Indiana University Press, 1999, pp. 377-403.
} 
policies." Fifth, foundations have "purchased services from (or subsidized the supply of services by) nonprofit and governmental agencies that provided health care, social welfare, educational, or cultural services." Finally, and perhaps most significantly in Hammack's view, philanthropic foundations have "sponsored the creation of new, or the reorientation and reorganization of existing, service providers." 5

In short, foundations have worked indirectly to develop new ideas and to create an intellectual climate and clientele to promote their adoption; they have helped in the creation and promotion of certain public policies; and they have provided support for service providers and have used their financial influence to reorganize the provision of such services as perceived needs have changed. In all of this, however, foundations do not act alone. If, as the cultural critic Dwight Macdonald argued in his history of the FF, the business of a philanthropic foundation is "the business of giving away cash,"6 its success depends upon finding recipients for its grants and fellowships whose work and goals are in accord with the programs and goals of the foundation. As we will see, both Rockefeller and Ford found willing partners in Turkey whose goals coincided with the foundations' interests in the modernization of Turkey.

\section{Rockefeller Philanthropy in Turkey}

John D. Rockefeller provided some support to Baptist missionary and relief work during the Ottoman period, and both John D. Rockefeller, Jr. and the RF supported relief work among Greek and Armenian refugees after World War I. ${ }^{7}$ But by the time

${ }^{5}$ David C. Hammack, "Foundations in the American Polity, 1900-1950," in Lagemann, ibid., p. 44.

${ }^{6}$ Dwight Macdonald, The Ford Foundation: The Men and the Millions (1955; reissued with a new introduction by Frank Sutton), New Brunswick, Transaction Publishers, 1987, p. 3; quoted in Hammack, ibid., p. 44.

${ }^{7}$ Rockefeller Family Archives, Record Group 2, Office of the Messrs Rockefeller, World Affairs series, box 41, folder 356, contains material covering the years 1896-1925 and labeled the Near East Relief Committee. The earliest material there is several letters dated March 1896 from Frederick D. Greene of the National Armenian Relief Committee to John D. Rockefeller, who gave a total of about $\$ 3,000$ toward Armenian relief 
Atatürk declared the new Turkish Republic, the RF was assuming its role as the leading American philanthropic foundation active on an international scale.

As in many countries throughout the world, the RF entered into work in Turkey through the foundation's program in public health. As early as 1917, Americans familiar with Turkey were urging the foundation to undertake efforts to improve public health in the country. "The need can scarcely be overstated," wrote one man who claimed to have experienced "ten years [of ] surgical work in Turkey". "As a disseminator of disease, the country is a distinct menace to Europe and America." 8 Staff of the RF did not simply accept the bleak and disparaging assessments it received from Americans associated with Christian missionary endeavors in Turkey. It sent its own experts to survey conditions. In August 1922 a foundation officer, Dr. Victor G. Heiser, spent ten days in Constantinople, visiting many charitable social welfare agencies and meeting with many people, including Admiral Mark Bristol, the US High Commissioner, who expressed great eagerness for the foundation to aid hospitals in Turkey. Indeed, over the next few

throughout 1896. Additional correspondence and telegrams to Rockefeller from this period also are included. Another body of material in the folder documents appeals to John D. Rockefeller, Jr. during the First World War, with related correspondence between JDR Jr.'s office and the officers of the Rockefeller Foundation, in which RF officials report on the RF's contributions and attitude toward relief work in the region. The Rockefeller Foundation gave a total of about $\$ 610,000$ to the Committee on Armenian and Syrian Relief, its officials reported to JDR Jr., and JDR Jr, appears to have given about $\$ 22,500$ during 1916-1918, but thereafter both the RF and the Rockefeller Family Office preferred to give through the Red Cross or Herbert Hoover's relief administration. On the RF and relief work, see the Rockefeller Foundation Archives, unpublished Rockefeller Foundation History, Source Material, which contains a section on War Relief (Volume 4) that provides a narrative summary of the Foundation's early work. Part IX: War in Europe and the First War Relief Commission (1914-1915) includes a section entitled "Turkey, December 1914-August 1915," pp. 899-919, and Part X: The Second War Relief Commission (1916-1917) includes a section entitled "Renewed Efforts in Turkey", pp. 1015-1034. The documents upon which this summary is based are located in the RFA, Record Group 1.1, series $100 \mathrm{~N}$, boxes 76-77, which include several folders on Turkish Relief.

${ }^{8}$ A. R. Hoover to Ernest C. Meyer, May 18, 1917, RFA Record Group 5, Series 1.2 , box 56 , folder 820 . 
years Bristol would become impatient with the foundation's cautious approach to Turkey, as officials continued to visit and compile reports but take no action. A report on "Medical Education in Turkey" was compiled in 1924, and Selskar Gunn visited in May 1925, detailing his contacts and impressions in a lengthy diary. ${ }^{9}$

By 1926, the political situation had stabilized in Turkey, which helped resolve some of the foundation's reticence about working there. The direction of the foundation's work in Turkey had become clear as well: it would provide fellowships to enable Turks to study abroad, and it would work with the Ministry of Health to develop an institute of public health. In addition, the foundation had found a man suitable for conducting work in Turkey, Dr. Ralph K. Collins, who arrived in the country in February 1926 and spent the next several months traveling and obtaining information, issuing his own comprehensive report on "Public Health in Turkey" in September $1926 .{ }^{10}$ Collins worked in Turkey until 1940, and was thus the key figure in the foundation's work in public health in Turkey during the 1920s and 1930s.

The most important project during this period was the development of the Central Institute of Hygiene in Ankara. The institute was to produce serum and vaccines, provide diagnostic laboratory services, and train personnel in public health work. The RF contributed $\$ 80,000$ for scientific equipment at the Institute. The foundation also provided $\$ 200,000$ toward the construction and equipment of a Service School to carry out the Institute's educational work. When in 1936 this school evolved into the School of Public Health, Dr. Collins became its first dean. ${ }^{11}$ The foundation recognized that nurses were an important component of the health care system, and in 1924 several representatives from the RF visited Turkey to investigate nursing practices and

\footnotetext{
${ }^{9} R F A, R G 1.1$, series 805 , box 1 , folder 3-4.

${ }^{10} R F A, R G 1.1$, series 805 , box 1 , folders $1-2$.

${ }^{11}$ On the foundation's public health work in Turkey, see $R F A, R G 6.1$, Paris Field Office, Series 1.1, Prewar Correspondence, boxes 36-37, folders 443-461; $R G 5$, International Health Division, Series 1.2, Correspondence, Series 805 ; and $R G$. 1.1, series 805 , box 1, folders 8-12, and $R G 1.2$, series 805 , box 1 , folders $5-9$.
} 
education. A number of nurses received fellowships to study nursing in the US. ${ }^{12}$

Public health dominated the foundation's work in Turkey prior to 1940. With the outbreak of World War II, however, the foundation's work in all of Europe was interrupted. Dr. Collins left Turkey in 1940, and at least two Turkish fellows studying in the US were stranded there by the war, unable to return home.

Even before World War II ended, in March 1945, the new Minister of Health and Social Assistance, Dr. Sadi Konuk, wrote to the foundation to invite its personnel to return to Turkey. But the postwar phase of the foundation's work in Turkey was much more varied than in the earlier years. New areas of endeavor within Turkey now received support from the RF,, including the arts and humanities, the social sciences, science, and medical education. The expanded scope of RF support reflected Turkey's more prominent status as an important American ally and buffer against the spread of communism in the Cold War. The number of RF fellowships and grants awarded to Turks increased dramatically. Twenty economists and twelve political scientists were among the fellowship recipients. Academics in these disciplines, and journalists like Bülent Ecevit, were seen as strategic members of the society who would communicate to others the lessons they learned about Western economies, political systems, and traditions of free speech, a free press, and personal liberty. To make these lessons explicit within Turkey, the RF supported the development of American Studies programs at the University of Ankara and İstanbul University as part of its new emphasis on "area studies" within its humanities program to promote intercultural understanding. ${ }^{13}$

In terms of the largest RF grants received by Turkish institutions during the 1950 s and 1960 s, two institutions stand out:

\footnotetext{
${ }^{12}$ See $R F A$ RG 1.1 , series 805 , box 1, folders $5-7 ; R G$ 6.1, Series 1.1, box 37, folders 457, 459, and 461; and Fellowship Recorder Cards for Turkey.

${ }^{13}$ See $R F A$ RG 1.2, Series $805 \mathrm{R}$, box 8, folders 76-77, and boxes $10-11$, folders 102-111. Recipients of RF fellowships included four Americanists in literature Leman Yolaç Fotos, Ahmet Edip Uysal, Leyla M. Gören, and Necla Bengül -- and one American historian, Halil Inalcık. See the Fellowship Recorder cards for Turkey, RFA.
} 
Robert College in İstanbul, and the Hacettepe Faculty of Medicine at the University of Ankara.

\section{RF Support to Robert College}

The trustees of Robert College received two large grants during this period. The first and largest was a grant of $\$ 350,000$ in December 1956 to be used over a ten-year period to help train Turkish personnel to serve as faculty for the school and for the American College for Girls. Two years later Robert College received a five-year grant of $\$ 115,000$ to use in developing general education in the humanities at the two schools. ${ }^{14}$

Proud of its status as "the first American college to be established outside the United States," Robert College by the late 1950 s was seeking to strengthen its curriculum and its faculty and to play a more influential role in Turkish higher education. Officials were convinced that the college provided a valuable "type of instruction and a kind of college community life [based] on the American pattern" that Turkish universities could not provide, with "small classes, close student-faculty relations, an informal teachinglearning approach, [and] a humanistic emphasis." Still, despite their method of education, they realized that the school's degree "lack[ed] at least a full year's work of being the equivalent of a B.A. degree from a good American college or university," and found, moreover, that many graduates completed their education at the Turkish national universities. The college trustees also recognized that it was becoming increasingly difficult for them to attract faculty with Western training. They considered such training to be essential to maintain the school's educational approach, which enabled their students "to acquire a stamp, a point of view, [and] an approach to problems, which make them a force for good in public and private life in Turkey out of all proportion to their numbers."

The college trustees thus sought support from the RF for a program that would enable it to improve its faculty by training and hiring "gifted young Turks." These talented men and women

${ }^{14}$ See $R F A \quad R G 1.2$, series 805 , box 2 , folders $12-13$, "Robert CollegeTurkish Faculty Training, " and box 9, folders 89-91, "Robert College-Humanities." 
would be recruited from various fields and their further education through the doctorate at American or British universities would be financed by Robert College, with foundation funds. Upon the completion of their degrees they would be required to return to Robert College and teach for three years, after which they would be free to seek employment elsewhere if they desired. In this way the program not only would strengthen the Robert College faculty but also would "augment the flow of Western-trained scholars into the faculties of Turkish universities." Those who did leave for positions elsewhere would take with them "a kind of teaching experience and humanistic outlook... which would be a healthy influence upon the excessive formalism in Turkish universities where there is a tendency to regard students merely as names on a roster." The foundation also expected the "foreign experience" of these new faculty members to convince them of the importance of "research as a normal, even indispensable, university faculty function." The grant of $\$ 350,000$ was expected to finance the training of fifteen new faculty in this manner. By January 1967, the program had enrolled eighteen participants, only five of whom had completed the doctorate, seven still were continuing their studies, but six students had withdrawn before completing their doctorates. The foundation extended the grant another two years to enable students to complete their work.

The second grant to Robert College, in April 1958, involved support for the development of courses in the humanities that would focus on the interplay of eastern and western civilizations. Demand for such courses that avoided the biases of alien cultures was emerging throughout the Middle East, the foundation's officers argued, but "little or nothing has as yet been done in the area to provide an integrated educational experience which would help students in placing themselves first in the area's own traditions and then in relation to the modernization that has taken place in large measure through Western influence." The foundation hoped that this grant, as well as the work of humanities scholars from Turkey who had received foundation fellowships, would help address this problem not only at Robert College but throughout Turkey "and possibly even in the Arab states." 


\section{RF Support to Ihsan Doğramacı and Hacettepe University}

While Robert College received substantial support from the $\mathrm{RF}$, the person in Turkey who inspired the most foundation support during the $1950 \mathrm{~s}$ and $1960 \mathrm{~s}$ clearly was Dr. İhsan Dogramac1, who came to the foundation's attention in 1955 as a newly appointed professor and head of the Department of Child Health and Pediatrics at the University of Ankara Faculty of Medicine. That year he received a small grant that enabled him to visit departments of pediatrics and institutes of maternal and child health in Mexico and the US. Between 1956 and 1967, programs with which Doğramacı was associated received more than one million dollars in grants from the RF. ${ }^{15}$

Doğramac1 clearly impressed foundation officials as someone with the energy, drive and determination necessary to make an impact upon medical education in Turkey. His "charismatic leadership, energy, enthusiasm, and professional competence" earned their praise and inspired their confidence in him. Foundation staff discussions of Doğramacı describe him as a devoted physician concerned about the extremely high infant mortality in Turkey, determined to address the problem on a longterm basis by improving the education of pediatricians and other medical personnel, overthrowing the old German medical education system in favor of a teaching program based on modern American concepts and standards of teaching and research.

His was a program that the foundation readily embraced. Foundation officers were impressed that in establishing the Research Institute of Child Health, Dogramac1 had persuaded the city of Ankara to provide land for it and the national government to finance its construction. The foundation believed that his efforts could create "the environment for a reorganization of medical education not only in Turkey, but... for other Middle Eastern countries" as well, since about ten percent of the medical students in Ankara come from Iraq, Lebanon, Syria, Iran and Afghanistan. The foundation supported Doğramacı's work enthusiastically. Between 1956 and 1964, the Doğramaci's projects received three grants totalling $\$ 415,000$, and in 1964 the foundation provided

${ }^{15}$ See $R F A, R G 1.2$, Series 805 , box 3 , folder 21 , and boxes $4-5$, folder 32 44. 
$\$ 225,000$ for the development of the Hacettepe Faculty of Medicine under Doğramacı's direction. Doğramacı's involvement also was a significant factor in the foundation's willingness to provide $\$ 110,000$ for a three-year period beginning in 1962 to support the educational programs of the new School of Nursing and Health Sciences at the University of Ankara. ${ }^{16}$

In early 1967 Doğramacı persuaded the foundation to grant the Hacettepe Science Center $\$ 250,000$ for use over a four-year period to develop family planning clinics for research, training, and demonstrations in the field of population control. ${ }^{17}$ These files show evidence of Doğramacı's political savvy. In 1965 the Turkish parliament narrowly repealed its anti-contraception laws and passed a Family Planning Law that established a national family planning program to be conducted through the Ministry of Health and Social Assistance. The foundation noted with pride that a key figure in changing the government's policy, Dr. Nusret Fişek, had been a foundation fellow. But vociferous opposition to family planning and population control made progress in implementing the program slow. Doğramacı believed that his medical center and its clinics were well suited to advance the family planning program, but he knew that including a budget line for such a program in a budget that must be approved by Parliament would spell political trouble. Thus, he turned to the RF for funds for equipment and for the salaries of doctors and nurses who would work on family planning projects at the Ankara and Erzurum medical centers and at a clinic in the Gülveren section of Ankara. For their part, foundation officials were mystified as to why Doğramacı was making such a request, since he usually had no trouble securing local funds for such items, but when he explained the delicate political situation during a meeting with a foundation official in April 1966, the situation became clear, and foundation support was forthcoming.

As these grants suggest, the RF found institutions and individuals within Turkey who shared its goal of modernizing various aspects of Turkish life. The RF was fairly traditional in its grant-making in Turkey during the 1950s and 1960s. Much of its

${ }^{16}$ For the School of Nursing, see $R F A, R G 1.2$, Series 805 , box 5-6, folders 49-52.

${ }^{17} R F A, R G 1.2$, Series 805 , box 2 , folders $15-16$. 
funding went for medicine and public health and university-based programs in the arts, humanities, and social sciences. But as the 1960 s came to a close, the foundation's program in Turkey began to shrink and agricultural development came to dominate its work there. As early as 1966 foundation staff were thinking of expanding upon the successes of its Mexican Agricultural Program and the Green Revolution its scientists created with an agricultural research and demonstration program for the Near East and Africa. In 1969 the RF entered into a formal agreement with the Turkish government to locate its Middle Eastern Wheat Program in Turkey with assistance from the International Maize and Wheat Improvement Center (CIMMYT). By July 1970 the foundation had established an agricultural sciences field office in Ankara under the direction of Bill C. Wright. ${ }^{18}$

\section{The Ford Foundation in Turkey}

Discussions about the wheat improvement project illustrate how collaborative an effort international philanthropy had become by the mid 1960s. These discussions involved not only RF and CIMMYT personnel but also representatives from various agencies of the US federal government and the FF. ${ }^{19}$ The FF had been active in Turkey since the early 1950s, and had opened its own field office there in 1960. Its grantmaking program in Turkey was less traditional than that of the RF: it collaborated with the Turkish government much earlier in the Cold War period than did the RF, and Ford's grantmaking was not as bound to the university campus as was Rockefeller's.

The FF was established in 1936 in Detroit, Michigan, as a distinctly local philanthropy. But with the death of Edsel Ford in 1943 and his father Henry in 1947, the foundation soon owned

${ }^{18}$ For the Turkish Wheat Improvement Program, see RFA box R2002 (unprocessed material), and the Ankara field office files (also unprocessed) and RF annual reports for 1969 and 1970.

${ }^{19}$ See John W. Gibler to Sterling Wortman, December 29, 1966, enclosing a carbon copy of Gibler to Norman Borlaug, December 28, 1966, in RFA box R1295. Gibler's letter to Borlaug summarizes their trip to the Near East and Africa and their discussions with various governments and U.S. federal agencies about setting up a regional program, which was initially proposed for Lebanon. 
$90 \%$ of the stock of the Ford Motor Company. Beginning in 1950, the foundation embarked upon what Dwight Macdonald has called its "global era." Taking an American foundation into international activity in the early stages of the Cold War meant that the leaders of the FF shared the concerns and fears of their government and the majority of their countrymen about the spread of communism and the influence of the Soviet Union. Former FF program officer Frank Sutton recalls that, specifically in terms of its policies in Asia and the Middle East, foundation officers had foremost in their minds the free world's perceived "loss" of China, and a consequent concern with the large rural populations of developing nations like Turkey. ${ }^{20}$ In 1952 the foundation sent a commission to visit the Near East and was advised "to concentrate its support on economic and social research, vocational education, village development, and leadership training." 21 The rural bias did not last long in Turkey, however. Between 1952 and 1962, the foundation made grants of $\$ 5.2$ million to Turkey. The two largest total grants of just over \$1 million each went to National Science Lise (through the Ministry of Education) and to the Institute of Business Administration at the Faculty of Economics of the University of İstanbul. Another $\$ 883,000$ went to Robert College and the American College for Girls. 22

As Table 3 and Appendix B show, the FF supported development projects in three main areas in Turkey: science, business and industry, and the social sciences. Looked at one way, the FF helped support the development of professional capacity in these three sectors. From another perspective, Ford sought to increase the influence of foreign expertise in Turkey. As one review of the foundation's work noted, "The typical Foundation grant in Turkey provides funds for three major components of a project: training abroad for Turks, foreign specialists working in

${ }^{20}$ Macdonald, The Ford Foundation: The Men and the Millions, p. 130; Frank Sutton, Remarks at the conference "Philanthropy and the City: An Historical Overview," September 26, 2000, Graducate Center, City University of New York.

${ }^{21}$ Ford Foundation Annual Report, 1952, p. 16.

${ }^{22}$ Harvey P. Hall and Eugene P. Northrop, "The Ford Foundation in Turkey:1952-1962," (February 1963), Ford Foundation Report, No. 002046 1963, Ford Foundation Archives. 
Turkey, and imported equipment and supplies."23 The tension inherent in drawing upon foreign expertise in order to develop and promote knowledge and ability among native Turks had been a persistent problem since the RF's work in public health in the 1920 s and 1930s.

\section{Conclusion}

If we return to Hammack's delineation of the specific endeavors foundations use to try to achieve their goals, ${ }^{24}$ we find that in Turkey the Rockefeller and Ford foundations used most of the steps Hammack identifies. Both foundations provided direct support for scientific and scholarly research across a range of disciplines. By using fellowships and grants to support strategic professions such as journalists, economists and other academics and organizations such as the Turkish Management Association and the Economic and Social Studies Conference Board, Ford and Rockefeller also worked indirectly "to shape public opinion by supporting studies that highlight particular problems and devise and advance particular policies." Its support for İhsan Doğramacı shows that the RF clearly sought to "support... those whose actions [it] consider[ed] exemplary."

Did the American foundations "help... [to] devise and promote specific government policies?" Certainly both foundations worked closely with the Turkish government on specific projects; the RF in public health in the 1930s and agriculture in the 1970s, and the FF in science education. But a closer examination of the grant files is necessary to determine whether the foundations were leaders or followers in policy development. The foundations were less active in the routine purchase of services from nonprofit and governmental agencies that provided health care, social welfare, educational, or cultural services, but they clearly sought to create new and reorient and reorganize existing institutions in health care, education, business, and agriculture, each of which was seen as a strategic segment of Turkish society through which modern ideas

\footnotetext{
${ }^{23}$ Ford Foundation, International Division, Middle East and Africa, "The Ford Foundation in Turkey, 1952-1971," (Ankara, 1972), Ford Foundation Report, No. 002924, Ford Foundation Archives.

${ }^{24}$ Hammack, "Foundations in the American Polity, 1900-1950," p. 44.
} 
and attitudes could gain a foothold and spread throughout the population.

Frank Sutton, a former program officer for the FF, once noted that "in some sense, in lesser or grander scale and time perspectives, all serious foundation programs are attempts to change the course of history." 25 In their own ways, both the Ford and Rockefeller foundations sought to affect the course of history through their work in Turkey, even though the amount of money each foundation devoted to Turkey was only a small portion of its overall funding. They aimed to modernize Turkey and improve the lives of its citizens, to improve life materially for the people of Turkey and to strengthen the institutions of civil society. In doing so they hoped to bring Turkey more firmly into the family of Western democracies, beyond the reach of communism and the Soviet Union's sphere of influence.

\footnotetext{
${ }^{25}$ Frank Sutton, "International Philanthropy in a Large Foundation," in Jack Salzman (ed.), Philanthropy and American Society: Selected Papers, New York, Center for American Culture Studies, Columbia University, 1987, p. 146.
} 
Table 1. Rockefeller Foundation Support for Turkey

\begin{tabular}{|c|c|c|}
\hline Decade & $\begin{array}{c}\text { Fellowships, } \\
\mathbf{1 9 2 5 - 1 9 8 3}\end{array}$ & $\begin{array}{c}\text { Grants, } \\
\mathbf{1 9 2 9 - 1 9 6 7}\end{array}$ \\
\hline $1920 \mathrm{~s}$ & 16 & $\begin{array}{c}1 \\
\text { (in 1929) }\end{array}$ \\
\hline $1930 \mathrm{~s}$ & 26 & $\begin{array}{c}9 \\
\text { (all in public health) }\end{array}$ \\
\hline $1940 \mathrm{~s}$ & 7 & 0 \\
\hline $1950 \mathrm{~s}$ & 62 & 78 \\
\hline $1960 \mathrm{~s}$ & 28 & 31 \\
\hline $1970 \mathrm{~s}$ & 13 & N/A \\
\hline $1980 \mathrm{~s}$ & 6 & N/A \\
\hline
\end{tabular}

Note: Only 23 fellowships involved study in a state other than the US

Table 2. Major Fields of Study of Turkish RF Fellows

\begin{tabular}{|l|c|}
\hline Field & Number \\
\hline Public health & 38 \\
\hline Agricultural sciences & $24(1969-1983)$ \\
\hline Medicine & 22 \\
\hline Economics & 20 \\
\hline Biological sciences & 16 \\
\hline Political Science & 12 \\
\hline Literature & 6 \\
\hline History & 2 \\
\hline
\end{tabular}

Source: Fellowship Recorder Cards, RFA, and Directory of Fellowships and Scholarships, 1917-1970, New York: RF, 1972.

Table 3. Summary of FF Support for Turkey, 1952-1971

\begin{tabular}{|l|r|}
\hline Science Development & $\$ 6,310,124$ \\
\hline Business and Industrial Development & $\$ 3,303,380$ \\
\hline Social Sciences & $\$ 1,386,800$ \\
\hline English Language for Turks & $\$ 644,550$ \\
\hline Other Grants & $\$ 2,754,264$ \\
\hline Other Program and Administrative Expenses & $\$ 1,658,255$ \\
\hline GRAND TOTAL & $\mathbf{\$ 1 6 , 0 5 7 , 3 7 3}$ \\
\hline
\end{tabular}




\section{Appendix A: Rockefeller Foundation Grant Files on Turkey ${ }^{26}$}

The list below is adapted from the finding aid the for RF Archives. It lists the institutions and individuals who received grants from the RF. Record Groups (RG) 1.1 and 1.2 are groups of material that were deposited in the archives at different times. Material in RG 1.2 documents the RF's increased grant-making in Turkey during the 1950 s and 1960 s, a time in which Turkey became a much closer ally of the US and a member of NATO as a result of its greater strategic and geographic importance during the Cold War.

This list does not include individuals who received fellowships from the foundation. These fellowship files are closed for research and in nearly all cases the files have been destroyed. Fellowship information is summarized on Fellowship Recorder Cards.

The material is organized by subseries as follows:

805 (no program letter; general material which does not fit into a particular program area)

805 A Medical sciences (research conducted in medical schools or medical research institutes, research directly applicable to the mental and physical health of human beings)

$805 \mathrm{C}$ Nursing (nursing education, public health nursing)

805 D Natural Sciences

805 E Fellowships (this material is not available for research)

805 I Malaria

805 L Public Health Education (schools of hygiene and public health)

$805 \mathrm{R}$ Humanities and the Arts

805 S Social Sciences

${ }^{26}$ Finding Aid, RF Archives, Sleepy Hollow, New York, Record Groups 1.1 and 1.2 Projects Series: 805 (Turkey) 


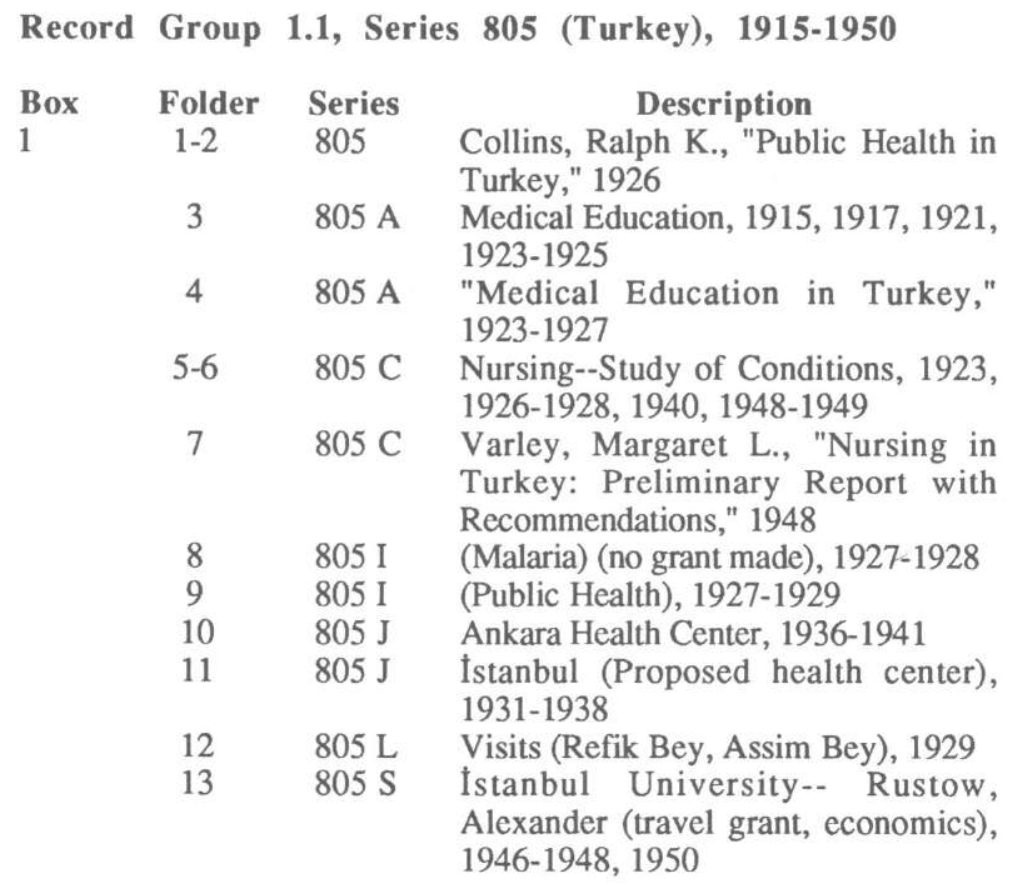

Record Group: 1.2, Series: 805 Turkey

\begin{tabular}{|c|c|c|c|}
\hline \multirow{4}{*}{$\begin{array}{l}\text { Box } \\
1\end{array}$} & Folder & Series & Description \\
\hline & 1 & 805 & $\begin{array}{l}\text { American Hospital of Istanbul-- } \\
\text { Eauinment. 1951-1953 }\end{array}$ \\
\hline & $2-4$ & 805 & Education--Visits, 1952-1955 \\
\hline & $5-9$ & 805 & $\begin{array}{l}\text { Institute of Hygiene, 1927-1941, } \\
1945,1950.1958-1963,1966.1968\end{array}$ \\
\hline \multirow[t]{6}{*}{2} & $10-11$ & 805 & $\begin{array}{l}\text { Institute of Hygiene--Supplementary } \\
\text { Material, } 1961,1966\end{array}$ \\
\hline & $12-13$ & 805 & $\begin{array}{l}\text { Robert College--Turkish Faculty } \\
\text { Training, 1956-1959, } 191-1967\end{array}$ \\
\hline & 14 & 805 & $\begin{array}{l}\text { University of Ankara--Ural, Zeki Faik, } \\
1952-1953,1956-1958\end{array}$ \\
\hline & $15-16$ & $805 \mathrm{~A}$ & $\begin{array}{l}\text { Hacettepe Science Center--Family } \\
\text { Planning, 1966-1971 }\end{array}$ \\
\hline & 17 & $805 \mathrm{~A}$ & $\begin{array}{l}\text { Hacettepe Science Center--Nutrition, } \\
1965-1968\end{array}$ \\
\hline & 18 & $805 \mathrm{~A}$ & $\begin{array}{l}\text { Istanbul University--Pharmacology, } \\
\text { 1960-1961 }\end{array}$ \\
\hline 3 & 19 & $805 \mathrm{~A}$ & $\begin{array}{l}\text { İstanbul University--Physiology, } \\
1956-1960\end{array}$ \\
\hline
\end{tabular}




\begin{tabular}{|c|c|c|c|}
\hline Box & Folder & Series & Description \\
\hline \multirow[t]{8}{*}{3} & 20 & $805 \mathrm{~A}$ & $\begin{array}{l}\text { İstanbul University--Terzioğlu, } \\
\text { Meliha, 1956-1959 }\end{array}$ \\
\hline & 21 & $805 \mathrm{~A}$ & $\begin{array}{l}\text { University of Ankara--Doğramacı, } \\
\text { Insan, 1955, 1958-1959 }\end{array}$ \\
\hline & 22 & $805 \mathrm{~A}$ & $\begin{array}{l}\text { University of Ankara--Ertuğrul, Ali, } \\
1962\end{array}$ \\
\hline & 23 & $805 \mathrm{~A}$ & $\begin{array}{l}\text { University of Ankara--Kantemir, tzzet, } \\
\text { 1954-1955 }\end{array}$ \\
\hline & $24-28$ & $805 \mathrm{~A}$ & $\begin{array}{l}\text { University of Ankara--Medical School, } \\
1956-1960\end{array}$ \\
\hline & 29 & $805 \mathrm{~A}$ & $\begin{array}{l}\text { University of Ankara--Nute, William } \\
\text { L., Jr. 1960-1961 }\end{array}$ \\
\hline & 30 & $805 \mathrm{~A}$ & $\begin{array}{l}\text { University of Ankara--Örnek, Sevim } \\
\text { Bike, 1955-1957 }\end{array}$ \\
\hline & 31 & $805 \mathrm{~A}$ & $\begin{array}{l}\text { University of Ankara--Paykoç, Zafer, } \\
1959-1960\end{array}$ \\
\hline 4 & $32-39$ & $805 \mathrm{~A}$ & $\begin{array}{l}\text { University of Ankara--Pediatrics, } \\
1953,1955-1963\end{array}$ \\
\hline \multirow[t]{7}{*}{5} & $40-43$ & $805 \mathrm{~A}$ & $\begin{array}{l}\text { University of Ankara--Pediatrics, } \\
\text { 1964-1968 }\end{array}$ \\
\hline & 44 & $805 \mathrm{~A}$ & $\begin{array}{l}\text { University of Ankara--Pediatrics-- } \\
\text { Symposium. 1961, } 1963\end{array}$ \\
\hline & 45 & $805 \mathrm{~A}$ & $\begin{array}{l}\text { University of Ankara--Say, Mehmet } \\
\text { Burhanettin, } 1962\end{array}$ \\
\hline & 46 & $805 \mathrm{~A}$ & $\begin{array}{l}\text { University of Ankara--Sökmen, Cavit, } \\
\text { 1958-1959 }\end{array}$ \\
\hline & 47 & $805 \mathrm{~A}$ & $\begin{array}{l}\text { University of Ankara--Visits, } \\
1958-1959\end{array}$ \\
\hline & 48 & $805 \mathrm{C}$ & $\begin{array}{l}\text { American Hospital of Istanbul--Deniz, } \\
\text { Esma, 1953-1954 }\end{array}$ \\
\hline & $49-51$ & $805 \mathrm{C}$ & University of Ankara, 1961-1963 \\
\hline \multirow[t]{8}{*}{6} & 52 & $805 \mathrm{C}$ & $\begin{array}{l}\text { University of Ankara, 1963-1964, } \\
1966\end{array}$ \\
\hline & 53 & 805D & Öztan, Nezihe, 1959 \\
\hline & 54 & 805D & $\begin{array}{l}\text { Robert College--Science Teaching, } \\
\text { 1956-1959 }\end{array}$ \\
\hline & $55-56$ & $805 \mathrm{E}$ & $\begin{array}{l}\text { Atkus, Erol Yaşar, 1969-1972 } \\
\text { CLOSED }\end{array}$ \\
\hline & 57 & $805 \mathrm{E}$ & Bayraktar, Ali, 1969-1972 CLOSED \\
\hline & $58-59$ & $805 \mathrm{E}$ & Dutiu, Cevdet, 1970-1973 CLOSED \\
\hline & 60 & $805 \mathrm{E}$ & $\begin{array}{l}\text { Izgin, Cemal Nadir, 1971-1974 } \\
\text { CLOSED }\end{array}$ \\
\hline & $61-62$ & $805 \mathrm{E}$ & Solen, Polet, 1968-1973 CLOSED \\
\hline \multirow[t]{2}{*}{7} & $63-64$ & $\begin{array}{l}805 \mathrm{E} \\
805 \mathrm{P}\end{array}$ & Ünver, Ergin 1968-1972 CLOSED \\
\hline & 65 & $805 \mathrm{R}$ & Dereli, Hamit, 1955 \\
\hline
\end{tabular}




\begin{tabular}{|c|c|c|c|}
\hline Box & $\begin{array}{l}\text { Folder } \\
66\end{array}$ & $\begin{array}{l}\text { Series } \\
805 \mathrm{R}\end{array}$ & $\begin{array}{c}\text { Description } \\
\text { Education Books, 1951-1953 }\end{array}$ \\
\hline 7 & $67-68$ & $805 \mathrm{R}$ & $\begin{array}{l}\text { Eyüboğlu, Bedri Rahmi, 1952-1953, } \\
\text { 1958-1963 }\end{array}$ \\
\hline \multirow{3}{*}{7} & 69 & $805 \mathrm{R}$ & Fureya, H. (Koral), 1956-1957 \\
\hline & 70 & 805R & $\begin{array}{l}\text { Institute for the Study of the Turkish } \\
\text { Revolution, 1952-1955 }\end{array}$ \\
\hline & $71-73$ & $805 \mathrm{R}$ & $\begin{array}{l}\text { İstanbul Municipal Conservatory, } \\
1956-1960\end{array}$ \\
\hline \multirow[t]{11}{*}{8} & 74 & $805 \mathrm{R}$ & $\begin{array}{l}\text { İstanbul Municipal Theatre--Devrim, } \\
\text { Sirim, 1961, 1963-1964 }\end{array}$ \\
\hline & 75 & $805 \mathrm{R}$ & $\begin{array}{l}\text { Istanbul Municipal Theatre-- } \\
\text { Sağıroğlu, Duygu, 1962-1964 }\end{array}$ \\
\hline & 76 & $805 \mathrm{R}$ & $\begin{array}{l}\text { Istanbul University--American } \\
\text { Studies, 1954-1956 }\end{array}$ \\
\hline & 77 & $805 \mathrm{R}$ & $\begin{array}{l}\text { Istanbul University--American } \\
\text { Studies, Turhan, Vahit, 1953-1955, } \\
\text { 1958-1961 }\end{array}$ \\
\hline & 78 & $805 \mathrm{R}$ & Istanbul University--Iz, Fahir, 1956 \\
\hline & 79 & $805 \mathrm{R}$ & $\begin{array}{l}\text { Istanbul University--Moran, Berna, } \\
1956,1961\end{array}$ \\
\hline & 80 & $805 \mathrm{R}$ & $\begin{array}{l}\text { Istanbul University--Near Eastern } \\
\text { Studies--Visits, 1955-1956 }\end{array}$ \\
\hline & 81 & $805 \mathrm{R}$ & $\begin{array}{l}\text { Istanbul University--Tanpınar, Ahmed } \\
\text { Hamdi, 1958-1960 }\end{array}$ \\
\hline & 82 & $805 \mathrm{R}$ & $\begin{array}{l}\text { Istanbul University--Timur, Hıfsı, } \\
1952-1953\end{array}$ \\
\hline & $83-84$ & $805 \mathrm{R}$ & $\begin{array}{l}\text { Istanbul University--Tunaya, Tarık. } \\
1954-1957 \text { (CLOSED material in } \\
\text { folder 83) }\end{array}$ \\
\hline & 85 & $805 \mathrm{R}$ & Kent Player's Theatre, 1962-1964 \\
\hline \multirow[t]{7}{*}{9} & 86 & $805 \mathrm{R}$ & $\begin{array}{l}\text { Presidential Symphony Orchestra, } \\
\text { Ankara, 1962,1965 }\end{array}$ \\
\hline & 87 & $805 \mathrm{R}$ & $\begin{array}{l}\text { Robert College--Garwood, David, } \\
1958-1959,1961\end{array}$ \\
\hline & 88 & $805 \mathrm{R}$ & Robert College--History, 1954-1958 \\
\hline & $89-91$ & $805 \mathrm{R}$ & $\begin{array}{l}\text { Robert College--Humanities, } \\
1956-1965\end{array}$ \\
\hline & $92-93$ & $805 \mathrm{R}$ & Saygun, A. Adnan, 1952-1959 \\
\hline & 94 & $805 \mathrm{R}$ & $\begin{array}{l}\text { Turkish-American University } \\
\text { Association--Katipoğlu, Sadun, } \\
1958-1960\end{array}$ \\
\hline & 95 & $805 \mathrm{R}$ & $\begin{array}{l}\text { Turkish-American University } \\
\text { Association--Modern Turkish History, } \\
\text { 1955-1960 }\end{array}$ \\
\hline
\end{tabular}




\begin{tabular}{|c|c|c|c|}
\hline Box & $\begin{array}{l}\text { Folder } \\
96\end{array}$ & $\begin{array}{l}\text { Series } \\
805 R\end{array}$ & $\begin{array}{l}\text { Description } \\
\text { Turkish-American University } \\
\text { Association--Turkish Research, } 1953\end{array}$ \\
\hline \multirow[t]{6}{*}{10} & 97 & $805 \mathrm{R}$ & $\begin{array}{l}\text { Turkish-American University } \\
\text { Association-- Turkish Research, } \\
\text { 1954-1955 }\end{array}$ \\
\hline & 98 & $805 \mathrm{R}$ & $\begin{array}{ll}\text { Turkish-American } & \text { University } \\
\text { Association--Turkish } & \text { Research-- } \\
\text { Reports, } 1953 & \end{array}$ \\
\hline & 99 & $805 \mathrm{R}$ & $\begin{array}{l}\text { Turkish State Conservatory, Ankara-- } \\
\text { Drama, 1957-1959 }\end{array}$ \\
\hline & 100 & $805 \mathrm{R}$ & $\begin{array}{l}\text { Turkish State Conservatory, Ankara-- } \\
\text { Sevin, Nureddin, 1956-1957 }\end{array}$ \\
\hline & 101 & $805 \mathrm{R}$ & $\begin{array}{l}\text { Turkish State Conservatory, Ankara-- } \\
\text { Turkay, Fuad, 1957-1960 }\end{array}$ \\
\hline & 102-107 & $805 \mathrm{R}$ & $\begin{array}{l}\text { University of Ankara--American } \\
\text { Studies, 1949-1956 }\end{array}$ \\
\hline \multirow[t]{6}{*}{11} & $108-111$ & $805 \mathrm{R}$ & $\begin{array}{l}\text { University of Ankara--American } \\
\text { Studies, } 1957-1960\end{array}$ \\
\hline & 112 & $805 \mathrm{R}$ & $\begin{array}{l}\text { University of Ankara--Kurat, Akdes } \\
\text { Nimet, 1949-1954 }\end{array}$ \\
\hline & $113-114$ & $805 \mathrm{R}$ & $\begin{array}{l}\text { University of Ankara--Literary } \\
\text { Criticism, 1951-1954 }\end{array}$ \\
\hline & 115 & $805 \mathrm{R}$ & $\begin{array}{l}\text { University of Ankara--Şahinhaş, Irfan, } \\
\text { 1952-1954 }\end{array}$ \\
\hline & 116 & $805 \mathrm{R}$ & $\begin{array}{l}\text { University of Ankara--Sayıll, Ayden, } \\
\text { 1952-1953 }\end{array}$ \\
\hline & 117 & $805 \mathrm{R}$ & $\begin{array}{l}\text { University of Ankara--Theatre } \\
\text { Institute, 1958-1960 }\end{array}$ \\
\hline \multirow[t]{6}{*}{12} & 118 & $805 \mathrm{R}$ & $\begin{array}{l}\text { University of Ankara--Turkish and } \\
\text { Islamic Art, 1959-1964 (CLOSED } \\
\text { MATERIAL WITHIN) }\end{array}$ \\
\hline & 119 & $805 \mathrm{R}$ & Yalman, Tune, 1962 \\
\hline & 120 & $805 \mathrm{R}$ & Yörükoğlu, Kadri Bey, 1951-1953 \\
\hline & 121 & $805 \mathrm{~S}$ & $\begin{array}{l}\text { Istanbul University--Economic } \\
\text { Development, 1955-1959 }\end{array}$ \\
\hline & 122 & $805 \mathrm{~S}$ & $\begin{array}{l}\text { Istanbul University--Economic } \\
\text { Development--Supplementary } \\
\text { Material, 1953, 1955-1957 }\end{array}$ \\
\hline & $123-125$ & $805 \mathrm{~S}$ & $\begin{array}{l}\text { Istanbul University--Economic } \\
\text { History, 1956-1964 }\end{array}$ \\
\hline \multirow[t]{2}{*}{13} & $126-127$ & $805 \mathrm{~S}$ & $\begin{array}{l}\text { İstanbul University--Economic } \\
\text { History--Supplementary Material, } \\
1949,1952,1954,1957,1960\end{array}$ \\
\hline & 128 & $805 \mathrm{~S}$ & $\begin{array}{l}\text { İstanbul University--Koran Readings, } \\
\text { 1956-1960, 1964-1967 }\end{array}$ \\
\hline
\end{tabular}




\begin{tabular}{|c|c|c|c|}
\hline Box & $\begin{array}{l}\text { Folder } \\
129\end{array}$ & $\begin{array}{l}\text { Series } \\
805 \mathrm{~S}\end{array}$ & $\begin{array}{l}\text { Description } \\
\text { Istanbul University--Sayın, Afife, } \\
\text { 1958-1962 }\end{array}$ \\
\hline \multirow[t]{3}{*}{13} & 130 & $805 \mathrm{~S}$ & $\begin{array}{l}\text { Robert College--Turkish Economic } \\
\text { Development, 1957-1962, } 1967\end{array}$ \\
\hline & $131-132$ & $805 \mathrm{~S}$ & $\begin{array}{l}\text { University of Ankara--Economic } \\
\text { Development, 1956-1959, 1961- } \\
1964,1966,1969\end{array}$ \\
\hline & $133-135$ & $805 \mathrm{~S}$ & $\begin{array}{l}\text { University of Ankara--Economic } \\
\text { Development--Supplementary } \\
\text { Material, 1954-1958, 1960-1961 }\end{array}$ \\
\hline \multirow[t]{9}{*}{14} & 136 & $805 \mathrm{~S}$ & $\begin{array}{l}\text { University of Ankara--Kurat, Akdes } \\
\text { Nimet, 1961-1963 }\end{array}$ \\
\hline & 137 & $805 \mathrm{~S}$ & $\begin{array}{l}\text { University of Ankara--Mardin, Şerif } \\
\text { Arif, 1961-1963 }\end{array}$ \\
\hline & 138 & $805 S$ & $\begin{array}{l}\text { University of Ankara--Mardin, Şerif } \\
\text { Arif--Report, } 1961\end{array}$ \\
\hline & 139 & $805 S$ & $\begin{array}{l}\text { University of Ankara--Mardin, Şerif } \\
\text { Arif--Reprints, 1960-1961 }\end{array}$ \\
\hline & $140-141$ & $805 \mathrm{~S}$ & $\begin{array}{l}\text { University of Ankara--Ökçün, Gündüz, } \\
\text { 1961-1964 }\end{array}$ \\
\hline & $142-143$ & $805 \mathrm{~S}$ & $\begin{array}{l}\text { University of Ankara--Ökç̧ün, Gündüz- } \\
\text {-Supplementary Material, } 1964\end{array}$ \\
\hline & 144 & $805 \mathrm{~S}$ & $\begin{array}{l}\text { University of Ankara--Smith, Edward } \\
\text { C., 1956-1958 }\end{array}$ \\
\hline & 145 & $805 \mathrm{~S}$ & $\begin{array}{l}\text { University of Ankara--Soviet Studies, } \\
1959-1965\end{array}$ \\
\hline & 146 & $805 \mathrm{~S}$ & Yalçın, Aydın, 1956-1957, 1959-1961 \\
\hline
\end{tabular}


Appendix B: Ford Foundation Grants to Turkey, 1952-197127

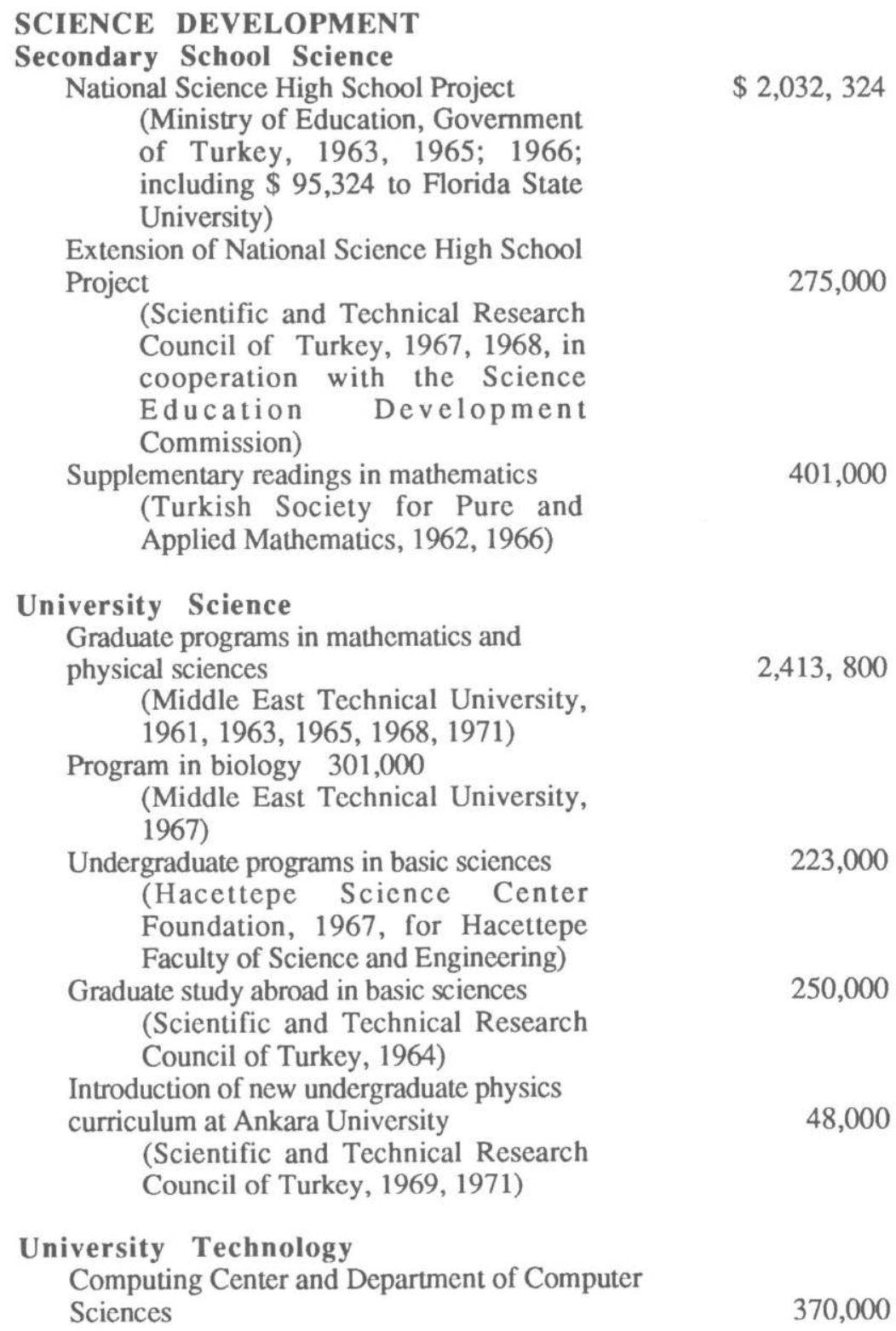

\section{University Science}

Graduate programs in mathematics and physical sciences

(Middle East Technical University, 1961, 1963, 1965, 1968, 1971)

Program in biology 301,000

(Middle East Technical University, 1967)

Undergraduate programs in basic sciences (Hacettepe Science Center Foundation, 1967, for Hacettepe Faculty of Science and Engineering) Graduate study abroad in basic sciences

(Scientific and Technical Research Council of Turkey, 1964)

Introduction of new undergraduate physics curriculum at Ankara University

(Scientific and Technical Research Council of Turkey, 1969, 1971)

\section{University Technology}

Computing Center and Department of Computer Sciences

27"The Ford Foundation in Turkey, 1952-1971", Report No. 002924, Ankara, 1972, FF Archives, New York. 
(Middle East Technical University, 1964, 1967)

Department of Restoration and Preservation

(Middle East Technical University, 1965, 1969)

Total Grants for Science Development

$\$ 6,310,124$

BUSINESS AND INDUSTRIAL DEVELOPMENT

Management Education and Training

Institute of Business Administration

$\$ 1,055,000$

(İstanbul University, 1954, 1959, 1962)

Participation in Congress of International

Committee for Scientific Management

(Turkish Management Association, 1963)

Management Development Center

(Turkish Management Association, 1964, 1965, 1966, 1968, 1971)

Activities preliminary to the establishment of a management education foundation

(Turkish Management Association, 1967)

Support for university-level business schools

(Management Education Foundation, 1969)

Research and Conferences on Development Problems

Conferences, research, and publications on

development

(Economic and Social Studies

Conference Board, 1961, 1964, 1970;

including $\$ 5,000$ to the

Turkish-American Education

Association)

Simultaneous translation facilities

(Economic and Social Studies

Conference Board, 1964, 1967, 1970)

Staff development and survey of research needs in education

(Turkish Education Foundation, 1967, 1970)

Research and advisory unit on business

and investment planning

(Economic Development Foundation, 1966)

Total Grants for Business and Industrial 
THE SOCIAL SCIENCES

Study of social change

(Turkish Social Science Association, 1967)

Improvement of social science education

$\$ 87,000$

(Turkish Social Science Association, 1971)

Institute of Population Studies

(Hacettepe Science Center

Foundation, 1967, 1970, for

Hacettepe Institute of Population Studies)

Department of Social Sciences

(Middle East Technical University, 1968, 1970)

Strengthening research and undergraduate

training in economics

(Hacettepe University - Robert

College, 1969)

Survey of studies on Turkish society

(Institute of Geography, Istanbul

University, 1969)

Research and instruction in cultural geography (Institute of Geography, İstanbul University, 1971)

Total grants for social sciences

\section{ENGLISH LANGUAGE FOR TURKS}

Preparation of English language teaching materials

(Robert College, 1962, 1964, 1966, 1968, 1970)

Preparatory year of English language training (Middle East Technical University, 1964)

Development of English language program

(Hacettepe Science Center Foundation, 1967, 1968, for

Hacettepe University, Department of Modem Languages) Intensive English language program (Bosphorus University, 1971) 


\section{OTHER FOUNDATION GRANTS}

Improvement of public education

$\$ 490,008$

(Ministry of Education, Government of Turkey, 1955, 1956, 1957, 1959, 1960)

Consultants in education

(Ministry of Education, Government of Turkey, 1954, 1956, 1957, 1958, 1959, 1961)

National Commission on Education

(Ministry of Education, Government of Turkey, 1958, 1960)

Institute of Librarianship (Ankara University, 1954, 1956, 1958,1962 , including grant of \$ 21,000 to the American Library Association)

International Legal Studies (İstanbul University, 1956)

Institute of Labor and Industrial Relations (İstanbul University, 1960)

Curriculum development and consultation (Middle East Technical University, 1960)

Turkish-English Dictionary

(American Board of Commissioners for Foreign Missions Publications Department, 1956, 1965)

English language, general support, and teacher recruitment programs

(Robert College and the American College for Girls, 1957, 1959, 1962, 1963)

Strengthening of educational programs

(American Academy for Girls in Üsküdar, 1953; and Admiral Bristol Hospital, 1952, 1955)

Study of educational program (Robert College, 1969)

Total for Other Foundation Grants

Total program, consultative and administrative

expenses $1,658,255$

GRAND TOTAL OF COMMITMENTS 1952- 30 September 1971 